\title{
ANALYSIS OF THE VALUE - ADDED FOR TAYAN BAUXITE ORE AND CHEMICAL GRADE ALUMINA
}

\author{
ANALISIS PENINGKATAN NILAI TAMBAH PENJUALAN BIJIH \\ BAUKSIT DAN CHEMICAL GRADE ALUMINA TAYAN
}

\author{
HARTA HARYADI \\ R\&D Centre for Mineral and Coal Technology \\ Jalan Jenderal Sudirman 623 Bandung 40211 \\ Ph. (+6222) 6030483, Fax. (+6222) 6003373 \\ e-mail: hartah@tekmira.esdm.go.id
}

\begin{abstract}
Research conducted at PT. ANTAM and PT. ICA (Indonesia Chemical Alumina) Tayan, West Kalimantan was aimed to compare the amount of company value-added from selling the bauxite ore as a raw material and the chemical grade alumina as a processed goods. This research showed that company value added from selling 850.000 tons raw meterial US $\$ 8.92$ million it consisted of salary and wages of US $\$ 692.42$ thousand, royalties, CSR and insurance US $\$ 473.87$ thousand, surveyor services US $\$ 150.00$ thousand, other services $\$ 45.00$ thousand, corporate income tax of US $\$ 1.64$ million, Bank interest US $\$ 191.77$ thousand. The company profits obtained the US $\$ 5,73$ million was. Of the US\$ 8.92 million added value and 850.000 bauxite selling, the increase of total added value was US\$ 10.49 per ton. Selling the chemical grade alumina up to 300,000 tons or equivalent to 850,000 tons provided the value-added to the US $\$ 57.24$ million that consisted of an increase in revenue salaries and wages to US\$ 3.85 million. 50.75 billion, royalties, CSR and insurance of US \$2.49 million, surveyor services and other services US \$16.50 million, corporate income tax $\$ 10.39$ million, Bank interest US \$1.21 million and corporate profits to the US \$22.00 million. The overall value added from selling the processed goods was US\$ 190.44 per ton. It is indicated that selling the chemical grade alumina provides a greater profit than that of selling the raw material.
\end{abstract}

Keywords: analysis, value-added, processing, bauxite, chemical grade alumina

\section{ABSTRAK}

Kegiatan penelitian di PT. ANTAM dan PT. ICA (Indonesia Chemical Alumina) di Tayan Kabupaten Sanggau, Kalimantan Barat, untuk mengetahui besarnya nilai tambah perusahaan bila menjual bauksit dalam bentuk bijih dan menjual dalam bentuk olahan berupa chemical grade alumina. Hasil penelitian menunjukkan, apabila perusahaan menjual bauksit dalam bentuk bijih sebanyak 850.000 ton diperoleh nilai tambah sebesar US\$ 8,92 juta yang terdiri dari pengeluaran gaji dan upah US\$ 692,42 ribu, royalti, CSR dan asuransi US\$ 473,87 ribu, jasa surveyor US\$150,00 ribu, jasa lainnya US\$ 45,00 ribu, PPh Badan US\$ 1,64 juta, bunga Bank US\$191,77 ribu dan keuntungan yang diperoleh perusahaan sebesar US\$ 5,73 juta. Dari total nilai tambah US\$ 8,92 juta dan penjualan bijih bauksit 850.000 ton diperolah nilai tambah sebesar US\$10,49 per ton. Terdapat peningkatan nilai tambah menjadi US\$ 57,24 juta apabila perusahaan menjual bauksit dalam bentuk chemical grade alumina 300.000 ton dari bahan baku bijih 850.000 ton yang terdiri atas peningkatan nilai tambah pendapatan gaji dan upah menjadi US\$ 3,85 juta, royalti, CSR dan asuransi US\$2,49 juta, jasa surveyor dan jasa lainnya US\$16,50 juta, PPh Badan US\$10,39 juta, bunga bank US\$1,21 juta dan keuntungan yang diperoleh perusahaan menjadi US\$22,00 juta. Dari total nilai tambah sebesar US\$ 57,24 juta dan penjualan chemical grade alumina sebanyak 300.000 ton diperoleh nilai tambah sebesar US\$190,44 per ton. Terbukti bahwa bahwa penjualan bauksit dalam bentuk chemical grade alumina, memberikan keuntungan (peningkatan nilai tambah) yang lebih besar dibandingkan dengan menjua bauksit dalam bentuk bijih.

Kata kunci: analisis, peningkatan nilai tambah, pengolahan, bauksit, chemical grade alumina 


\section{INTRODUCTION}

Commercially bauxite is used for abrasive, cement, chemical, metallurgical and refractory materials. Almost $90 \%$ of mined bauxite has been converted into alumina $\left(\mathrm{Al}_{2} \mathrm{O}_{3}\right)$ and the rest is beneficiated for nonmetllic usage such as chemical grade alumina (Amalia et al., 2011).

According to Salavati, (2010), processing bauxite into alumina, produced two products, namely smelter grade alumina (SGA) and chemical grade alimina (CGA). More or less $90 \%$ of the processing of bauxite in the world is used to produce smelter grade alumina (SGA), then continued to produce pure Al metal.

Currently, PT. ANTAM has already produced chemical grade alumina (CGA) trough its subsidiary, namely by PT. ICA (Indonesia Chemical Alumina and metallurgical grade alumina or smelter grade alumina (SGA) that will be produced in 2018 such a production is used to fulfil the need of PT. Inalum, Asahan as big as 550,000 tons/year. The SGA will be used for raw material to produce the aluminum metal. Currently, the alumina need of PT. Inalum is supplied by import. Therefore the specification of metallurgical grade alumina produced by PT. ANTAM should meet the specification applied by PT Inalum (Husaini et al., 2009).

In manufacturing the alumina, the there is a Bayer process that produces a red mud and sodium aluminate solution. The sodium aluminate solution is used to make alumina (Aziz et al., 2007).

Based on the updating data and balance of resources in 2014, Indonesia has a bauxite resource up to 3.617 .770 .88 tons and metals bauxite amounted to $1,740,461,414$ tons. The total ore resource is $5,358,232,296$ tons. Based on the Centre of Geological Resources (Pusat Sumber Daya Geologi, 2014 ), the ore reserves is $1,257,169,367$ tons and the bauxite mineral is 571.254 .869 tons performing the total reserve of $1,828,424,236$ tons. Until 2014, a number of bauxite resources and reserves do not provide the optimal benefits as the whole production resulted is marketed in the form of raw materials.
Indonesian bauxite is scattered in Riau Islands, West Kalimantan, Central Kalimantan and Bangka - Belitung Islands. West Kalimantan has quite large bauxite resources and reserves, namely $3,268,533,344$ tons and 1,129,154,090 tons, respectively (Dinas Pertambangan Propinsi Kalimantan Barat, 2015). A lot of resources and reserves will provide a very favorable prospect support the construction of bauxite processing and refining plants to be the alumina in this area because it can supply the raw materials for a very long period of time and provide significant profits for this alumina industry.

There are some bauxite deposits in West Kalimantan Province (Pusat Sumber Daya Geologi, 2014). The deposit belongs to laterite deposits. The area includes Tayan and surroundings at Sanggau regency performing $27-30 \% \mathrm{Al}$; Sandai, of Ketapang Regency containing $29.4 \% \mathrm{Al}$; Air Upas and Riam consists of $28-35 \%$ Al; Ketapang of Kendawangan Regency comprise 31\% Al; Sei Raya of Sambas regency presenting 47$53 \%$ Al. Some deposits perform a thickness between 1.5-2 $\mathrm{m}$ as found at Ketapang, Mungguk Pasir, Kusik, Simpang Dua, Kunyit Island, Balai Bekuak, Pantah, Dawak and Semandang Rivers.

There are 49 companies that retain bauxite mining business licence of MBL business licence or MBL, with the total area of 557,259 $\mathrm{Ha}$ and scattered at several regencies, among others: Sanggau 27 MBLs with total area of 247338 hectares; Bengkayang 2 MBLs performing area of 9,500 Ha; Landak 8 MBLs with the area of $57,217 \mathrm{Ha}$; North Kayong 5 MBLs possessing 9,85 Ha; Pontianak possessing $35,250 \mathrm{Ha}$; and he border area among regencies/cities 4 MBLs with the total area of $197.970 \mathrm{Ha}$ (Dinas Pertambangan Propinsi Kalimantan Barat, 2015). Sanggau and Ketapang, located in the border area of two regencies, retain the largest bauxite resources, namely 1.28 billion and 1.02 billion tons, respectively.

The expire date of the MBLs ranges from 2 to 20 years. Of the $49 \mathrm{MBL}$ hoders, three of them, namely PT. Antam, PT. Harita Prima and PT. Alu Sentosa have conducte bauxite mining from 2008 to 2011, the companies had exported the bauxite ores around $40,343,201$ tons (in $2008=7,097,647$ tons; in $2009=6,345,554$ tons; in $2010=12.5$ million tons; and in $2011=14.4$ million tons) to 
Japan and China. Other bauxite companies in West Kalimantan include PT. Putra Alam Lestari, PT. Putra Mining Group, PT. Mekko Mining Group, PT. Nusapati Prima Group and PT. Mahkotaku Group. Some companies in exploitation and ready-to-produce condition are PT. Mahkota Karya Utama, PT. Dinamika Sejahtera Mandiri, PT. Mega Citra Utama, PT. Danpac Resources, PT. Sanmas Mekar Abadi, PT. Kalmin, PT. Energi Bara Lestari, PT. Kapuas Bara Mineral and PT. Borneo Edo International.

Based on the long term contrack; to date, the Indonesian bauxite, especially from West Kalimantan have only exported to Japan and China. Yet, another marketing segment is awaiting if the Indonesian bauxite has been processed into the chemical grade or smelter grade alumina such as European contries as the biggest alumina consumers. As ilustration, when the alumina price at London market was US $\$ 400$ per metric ton, Indonesia did not get the benefit from this situation.

Law no. 4 of 2009 regarding Mineral and Coal Mining and Government Regulation No. 23 Year 2010 Implementation of Mineral and Coal Mining Business Activities considering certify that the mining products must be processed into finishing or semi-finishing commodities and is prohibited to be exported in the raw form in terms of gaining the value added and fulfilling the need of raw material for domestic industry. PT. Aneka Tambang and its company partner (Showa Denko of China) accepted such regulations by establishing PT. ICA (Indonesia Chemical Alumina) to process Indonesian bauxite into chemical grade alumina. The project site is located in Tayan, Sanggau Regency, West Kalimantan.

The plant of chemical grade alumina owned by PT. ICA has a capacity of 300,000 tons chemical grade alumina per year, by processing 1.7 million tons bauxite or that is equivalent to 850,000 tons washed bauxite the investment value is US\$ 450 million. In 2016, the first commercial action has been accomplished. The CGA produced by PT. ICA is used as a filler for cosmetics industry such as nail polish, lipstick and sunscreen/sunblock as well as a catalyst to dehydrate water within gas flog CGA is also employed as raw material for polishing the CD / DVD product as well as Another CGA application is a componenet of refractories, building materials, integrated circuit, LCD screen materials etc. The CGA project at mempawah is set up for 20 years or will be ended in 2036. Evaluation will be conducted at the of the project. The raw material for CGA plant is supplied by Tayan bauxite miner, owned by PT. Aneka Tambang. The resources or the mine is 188.30 million tons within a total area of 36.410 ha (PT. Aneka Tambang, 2015). The total need of bauxite raw material is 1.7 million tons of bauxite per year or is equivalent to 850,000 tons of washed bauxite. By assuming the production rate is fixed at 1.7 million tons, the mine life is about 110.76 years. It means that during 110.76 years, the CGA plant will survive due to the availability of bauxite resources owned by PT. Antam.

Research location is PT. ANTAM and PT. ICA in Tayan, Sanggau regency, West Kalimantan (Figure 1). This study is intended to examine the financial aspects of a commercial CGA plant construction and the possibility of the value added increase from direct selling the raw material compared to selling the material in form of chemical grade alumina.

\section{METHODOLOGY}

The method used in this study is a direct survey to get data and literature studies of the reports from PT. Aneka Tambang and PT. ICA.

The value-added is calculated using a formula as follows (Suripto, 2011).

Value-added $=f(K, B, T, U, H, h, I)$

Where :

$\mathrm{K}$ = production capacity

$\mathrm{B}=$ number of raw materials used

$\mathrm{T}=$ labor involved

$\mathrm{U}=$ labor Wage

$\mathrm{H}=$ output prices

h. $=$ prices of raw materials

$\mathrm{L}=$ additional Input

By the data and information obtained from the company on product sales of bauxite ore and chemical grade alumina as well as functions which describe the increase in value-added products (Kamisi, 2011), it was conducted an analysis of the sale calculation of value-added bauxite and chemical grade alumina using the method of value-adding (Slamet, 2005) are shown in Table 1. 
INDONESIAN MINING JOURNAL Vol. 19, No. 3, October $2016: 167$ - 178

Table 1. Method to calculate the increase of value added for production process

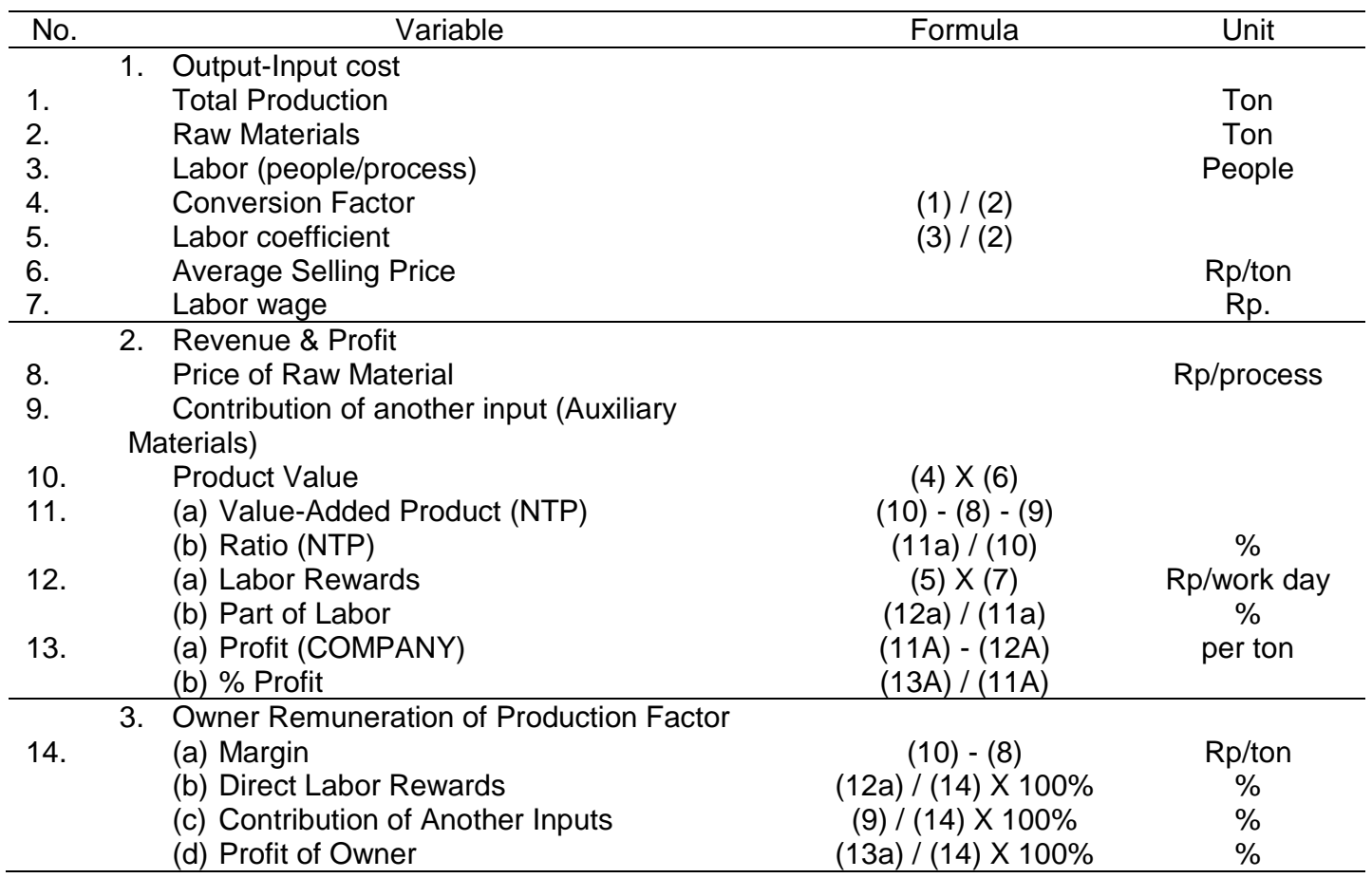

\section{RESULTS AND DISCUSSION}

PT. ICA is the CGA pioneer industry in Indonesia and the fifth country in the Asia Pacific region besides Japan, China, Australia, and Korea to process bauxite to become chemical grade alumina. It can be a trigger for alumina-based industries in Indonesia in the future. Chemical Grade Alumina (CGA) in general refers to the chemical product in the form of aluminum hydroxide and alumina is used for aluminum industry. Aluminum hydroxide is an intermediate product that can be used as a raw material for coagulant manufacturing that is usually used in water purification. While the alumina can be used to manufacture electronic component supporting materials. Some products that use the CGA include: refractories, abrasives, building product, Integrated Circuit (IC) as well as materials for the LCD screen.

Tayan CGA plant has processed bauxite reserves in Tayan, to produce 300,000 tons of chemical grade alumina per year (of 850,000 tons ore bauxite). The CGA product will be exported to Japan and other countries and also be sold to domestic market in Indonesia. The Processing of alumina in Tayan uses the Bayer process for treating bauxite ore with alumina products. Bayer process involves three stages namely continuous dissolution process (Liquor Clarification Process), Precipitation Process and Calcinations Process. Tayan CGA products will be supplied to the various industries that use alumina to produce detergent, paper, cement, coagulants, refractories, abrasives, polishing, ceramics, glasses and others. Tayan CGA factory will produce over 100 kinds of alumina hydrate and alumina products.

\section{Revenue}

Company revenue is gained from the number of bauxite ore production plus the number of CGA production multiplied by the sales price at that time.

\section{Raw Material Provision}

The CGA plant managed by PT. ICA is located at Tayan. The plant started selling its production in 2015. Based on the research results, raw material requiriments for one year production process (to produce 300.000 tons of chemical grade alumina), the raw material needed is as much as 1.7 million tons of bauxite, at a price of US\$19 or Rp. 
250,480 per tons (exchage rate of US\$ $=$ Rp. 13,180, Bank Indonesia, July 2016). The material used include raw and supporting materials. The raw material for CGA making is the bauxite ore while the supporting one is the caustic soda in terms speeding up the proces. The supporting material varies from on company to another one.

\section{Capital}

PT. ICA shared with Sowa Denko of Chinese for capital provision. The share consists of $80 \%$ for PT. ANTAM and $20 \%$ for Showa Denko. If PT. ICA uses either an equity of a company or loan capital, it is assumed as a credit and needs to pay the interest as prevailing at that time. The interest rate at that time was $5 \%$ a year.

\section{Expenditure}

The expenditure is calculated by subtracting the revenue. Its calculation is conducted to calculate the gross profit of the company prior tax deduction and comprises employee salaries, raw material cost, fuel expenses, transportation and services fees, environmental countermeasures charges, CSR and marketing fees, logistics and distribution charges as well as communication fees.

\section{Income}

Income is the net profit it is the income. It is the ratio of total revenue minus total costs and reduced corporate income tax.

\section{Value Added}

The results showed that if the company produces as many as 1.7 million tons of bauxite ore or equivalent to 850,000 tons of washed bauxite and sold in crude form at the US \$ 19 per ton (Bank Indonesia, 2016), based on the income statement approach, the value-added is US $\$ 8,923,273$ it consists of salary and wages amounting to the US \$ 692,416 , royalty, CSR and insurance amounting to the US $\$ 473,874$. Surveyor Services US $\$ 50,000$, Other Services amounted to US $\$ 45,000$, corporate income tax amounted to US $\$ 1,643,762$, Interest rate Bank amounting to US $\$ 191,772$, and Gains amounting to US \$5,726,449 (Table 2).

Of the US $\$ 8.92$ million added value and 850.000 bauxite selling, the increase of total added value was US\$10.49 per ton. In 2013 as the last year to export the bauxite (around 40 million tons) the value added was US\$ 419,918,729 (Table 2).

Calculation analysis showed that the valueadded of chemical grade alumina products (PT. Aneka Tambang, 2015) with a capacity of 300,000 tons and a selling price per ton CGA US $\$ 455$ is the US $\$ 57,238,237$. It comprises salary and wages amounting to US $\$ 3,850,900$, royalty, CSR and insurance US $\$ 2,490,000$, surveyor and other services US $\$ 16.5$ million, local taxes US $\$ 795,000$, corporate income tax US $\$ 10,389,373$, profit interest rate bank US $\$ 1,212,093$ and. Of US $\$ 57,238,237$-total value added and 300.000 ton chemical grade alumina-sales, it is obtained a value-added of US \$ 190.79 per ton. (Table 3). In 2013, the 40 million tons bauxite was equal to $7,058,823$ tons chemical grade alumina. Such a figure provided and added value around US $\$ 1,346,756,941$. Using common several measurement variables in analyzing the business sensitivity, i.e. lowering the CGA selling prices to $5 \%$ and increasing production costs to $5 \%$. The construction of CGA plant in Tayan is not sensitive to price reductions and production costs increase it means it that the company still getits profit.

If the selling price decreases to $5 \%$ then it will be the US $\$ 432$ per ton and will provide an added value of US $\$ 50,338,237$, gross operating surplus to the US $\$ 25,490,244$ and net operating surplus to the US $\$ 15,100,87$. Meanwhile, when production cost increases to $5 \%$, then the production cost will be the US $\$ 25,499,599$ and will provide the added value of US $\$ 56,023,971$ and the gross operating surplus to the US $\$ 31,175,978$ as well as the acquired net operating surplus to the US $\$ 20,786,605$. 
INDONESIAN MINING JOURNAL Vol. 19, No. 3, October $2016: 167$ - 178

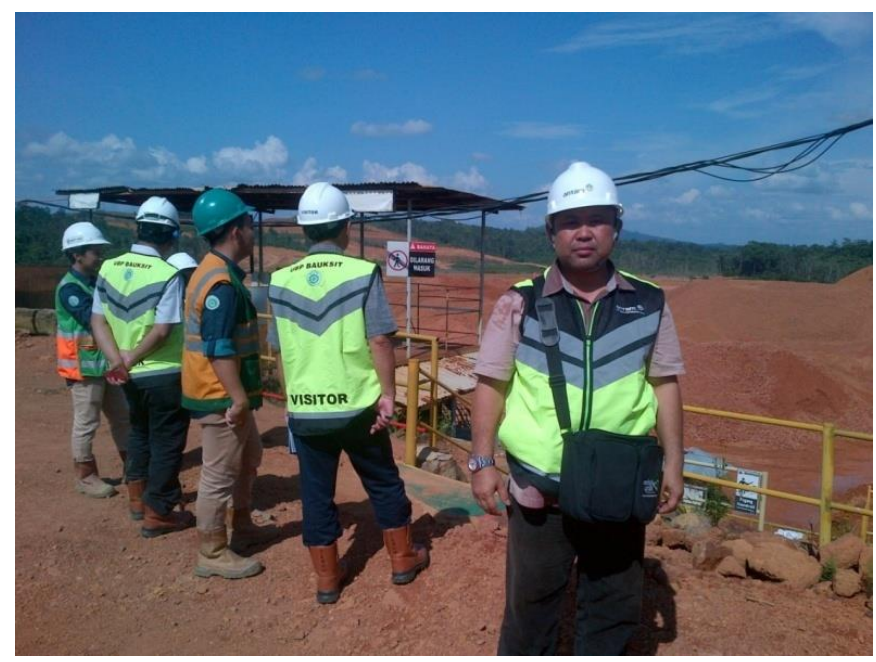

Figure 1. Location of bauxite mine PT. Antam, Tayan, Sanggau Regency

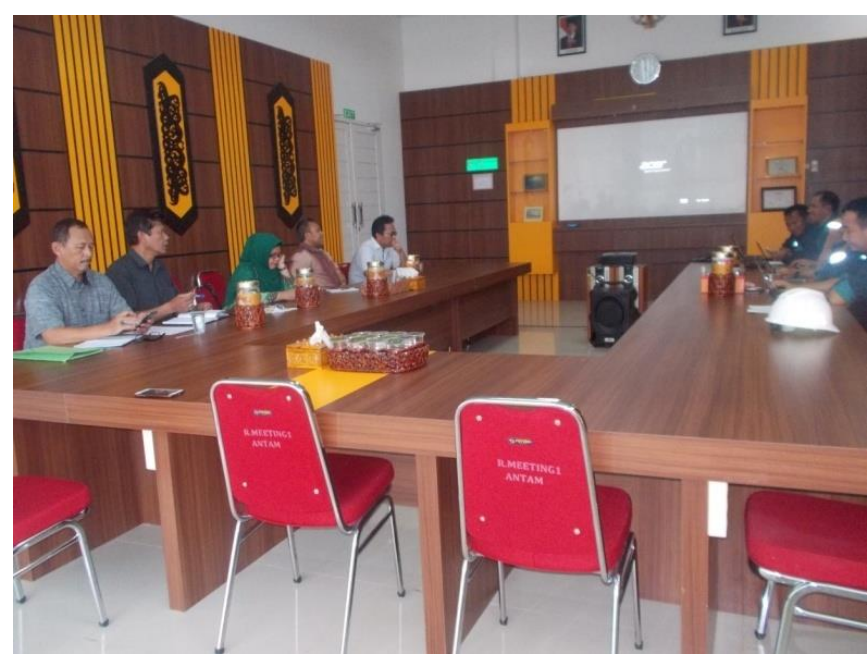

Figure 2. Discussion with management of PT. Antam

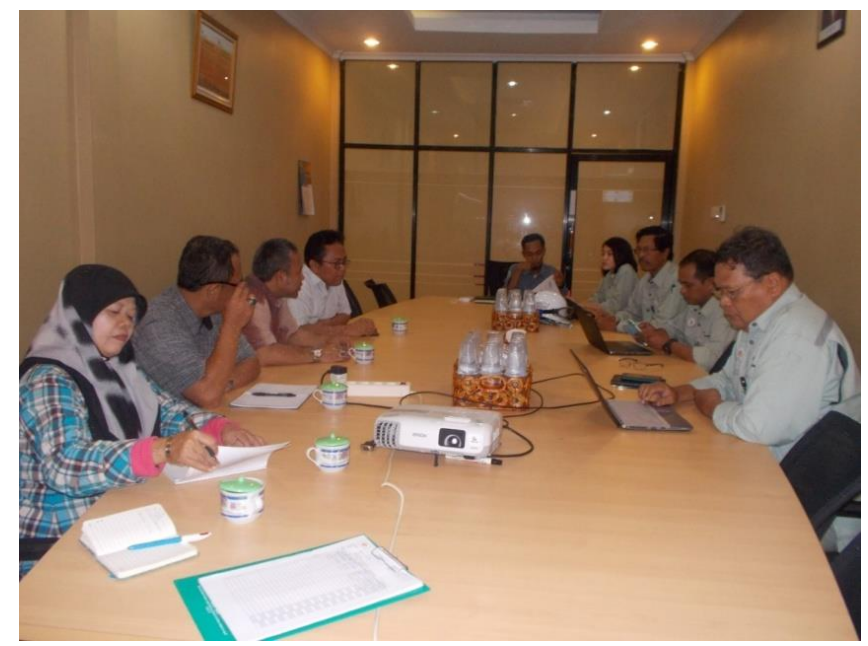

Figure 3. Discussion with management of PT. Indonesia Chemical Alumina (ICA) 
Table 2. Value-added of the company from selling bauxite ore

\begin{tabular}{|c|c|c|c|c|}
\hline No. & Description & $\begin{array}{l}\text { Cash flow } \\
\text { (US\$) }\end{array}$ & $\begin{array}{c}\text { Cash flow (total) } \\
\text { US\$ }\end{array}$ & Value-added \\
\hline \multirow[t]{3}{*}{1} & Revenue & $16,150,000$ & $16,150,000$ & \\
\hline & Bauxite ore production(ton) & 850,000 & & \\
\hline & Bauxite ore price/ton (US\$) & 19 & & \\
\hline 2 & Expenses & 692,416 & 692,416 & 692,416 \\
\hline $\mathrm{a}$ & Net management salary & 239,133 & & \\
\hline b & Net direct labor wage & 239,133 & & \\
\hline c & Management tax & 42,200 & & \\
\hline d & Direct tax labor & 94,600 & & \\
\hline $\mathrm{e}$ & Employment insurance & 77,350 & & \\
\hline 3 & Stationery & 2,000 & 2,000 & \\
\hline 4 & Fuel \& Oil & $2,105,665$ & $2,105,665$ & \\
\hline $\mathrm{a}$ & Fuel & $1,955,665$ & & \\
\hline b & Oil & 150,000 & & \\
\hline 5 & Spare Part & 300,000 & 300,000 & \\
\hline 6 & Depreciation \& Amortiation & $1,918,701$ & $1,918,701$ & \\
\hline 7 & Royalty, CSR, Environment & 473,874 & 473,874 & 473,874 \\
\hline a & Royalty & 365,250 & & \\
\hline b & CSR to the village & 38,624 & & \\
\hline $\mathrm{d}$ & Environmental countermeasures & 35,000 & & \\
\hline e & Reclamation & 35.000 & & \\
\hline 8 & Transportation \& Loading (Rental) & $2,500,000$ & $2,500,000$ & \\
\hline a & Transportation from barge to vessel & $1,250,000$ & & \\
\hline$b$ & Loading to vessel & $1,250,000$ & & \\
\hline 9 & Surveyor Service & 150,000 & 150,000 & 150,000 \\
\hline a & Cost of SGS/sample analysis & 75,000 & & \\
\hline $\mathrm{b}$ & Analysis \& draft of export survey & 75,000 & & \\
\hline 10 & Other Services & 45,000 & 45,000 & 45,000 \\
\hline a & Custom & 2,500 & & \\
\hline $\mathrm{b}$ & Representation & 5,000 & & \\
\hline c & Mining office & 5,000 & & \\
\hline$d$ & Navy & 2,500 & & \\
\hline e & Local government & 5,000 & & \\
\hline$f$ & Police & 2,500 & & \\
\hline q & Port authorities & 2.500 & & \\
\hline $\mathrm{h}$ & Voyage & 20,000 & & \\
\hline 11 & Overhead Cost & 592,133 & 592,133 & \\
\hline 12 & Total Cost & & $8,779,789$ & \\
\hline 13 & Bruto Surplus Bussiness & & $7,370,211$ & \\
\hline 14 & Corporatelncome Tax & $1,643,762$ & $1,643,762$ & $1,643,762$ \\
\hline 15 & Netto Surplus Bussiness & & $5,726,449$ & $5,726,449$ \\
\hline 16 & Interest Rate (5\%/tahun) & 191,772 & 191,772 & 191,772 \\
\hline 17 & Total Value-Added Of Bauxite Ore & & & $8,923,273$ \\
\hline
\end{tabular}

Table 3. Value-added of chemical grade alumina

\begin{tabular}{clrrr}
\hline No. & \multicolumn{1}{c}{ Description } & $\begin{array}{r}\text { Cash flow } \\
(\text { US } \$ \text { ) }\end{array}$ & $\begin{array}{r}\text { Cash flow } \\
\text { (total) US } \$\end{array}$ & Value-added \\
\hline 1 & Revenue & $136,500,000$ & $136,500,000$ & \\
& Production of Chemical Grade Alumina(ton) & 300,000 & \\
& CGA Price/ton (US $\$$ ) & 355 & & $3,850,900$ \\
\hline 2 & Expenses of Salary & $3,850,900$ & $3,850,900$ & \\
a & Management 10 People & 200,000 & \\
b & Engineer 75 People & $1,200,000$ & \\
c & Supervisor 70 People & 700,000 & \\
d & Executor 160 People & 960,000 & \\
e & Employee Taxes & 459,000 & \\
f & Employee Insurance & 331,900 & \\
\hline
\end{tabular}


INDONESIAN MINING JOURNAL Vol. 19, No. 3, October $2016: 167$ - 178

\begin{tabular}{|c|c|c|c|c|}
\hline No. & Description & $\begin{array}{l}\text { Cash flow } \\
\text { (US\$) }\end{array}$ & $\begin{array}{l}\text { Cash flow } \\
\text { (total) US\$ }\end{array}$ & Value-added \\
\hline 3 & Raw Materials in Process & $24,285,333$ & $24,285,333$ & \\
\hline a & Bauxite Ore850.000 ton & $13,680,000$ & & \\
\hline $\mathrm{b}$ & Caustic soda & $3,672,000$ & & \\
\hline $\mathrm{c}$ & Electricity $260 \mathrm{KwH} / \mathrm{TON}$ & $6,933,333$ & & \\
\hline 4 & Fuel/Transportation/etc. & $43,750,000$ & $43,750,000$ & \\
\hline a & Fuel (oil/vat) etc. & $12,000,000$ & & \\
\hline $\mathrm{b}$ & Part, Supplies & $7,500,000$ & & \\
\hline $\mathrm{C}$ & Electricity to light the plant \&office & 850,000 & & \\
\hline d & Depreciation & $22,500,000$ & & \\
\hline $\mathrm{e}$ & Safety & 150,000 & & \\
\hline $\mathrm{f}$ & Tailing, processing & 750,000 & & \\
\hline 5 & Services & $16,500,000$ & $16,500,000$ & $16,500,000$ \\
\hline a & Transportation services/lease & $12,500,000$ & & \\
\hline $\mathrm{b}$ & Traveling & $1,250,000$ & & \\
\hline $\mathrm{C}$ & Other operational & $1,250,000$ & & \\
\hline $\mathrm{d}$ & Facilities & $1,500,000$ & & \\
\hline 6 & Environment/Comdev & $2,490,000$ & $2,490,000$ & $2,490,000$ \\
\hline a & Environmental countermeasures & $1,250,000$ & & \\
\hline $\mathrm{b}$ & CSR & 240,000 & & \\
\hline $\mathrm{c}$ & Infrastructure development/natural disaster & $1,000,000$ & & \\
\hline 7 & Marketing/Logistics/Distribution/Communication & $3,250,000$ & $3,250,000$ & \\
\hline a & Marketing fee & $1,250,000$ & & \\
\hline $\mathrm{b}$ & Logistic/distribution fee & $1,250,000$ & & \\
\hline $\mathrm{c}$ & Communication fee & 750,000 & & \\
\hline 8 & Local Taxes & 795,000 & 795,000 & 795,000 \\
\hline a & Property taxes, local taxes & 450,000 & & \\
\hline $\mathrm{b}$ & Vehicle taxes & 120,000 & & \\
\hline $\mathrm{C}$ & License \& other taxes & 225,000 & & \\
\hline 9 & Overhead Cost & $9,188,523$ & $9,188,523$ & \\
\hline 10 & Total cost & & $104,109,756$ & \\
\hline 11 & Bruto surplus bussiness & & $32,390,244$ & \\
\hline 12 & Corporate income tax & $10,389,373$ & $10,389,373$ & $10,389,373$ \\
\hline 13 & Netto surplus bussiness & & $22,000,871$ & $22,000,871$ \\
\hline 14 & Interest rate (5\%/year) & $1,212,093$ & $1,212,093$ & $1,212,093$ \\
\hline 15 & Total value-added of bauxite ore & & & $57,238,237$ \\
\hline
\end{tabular}

Sources: PT. ANTAM dan PT. ICA

Note : August 20161 US\$ = Rp. 13,180 (Bank Indonesia, 2016)

In terms of preserving the mandate implementation of the Law of the Republic of Indonesia No. 4 of 2009 concerning Mineral and Coal Mining notably those that are related to the obligations of domestic mineral processing and refining, the Minister of Energy and Mineral Resources has issued Regulation No. 8 of 2015 . The regulation is issued due to until 2016 no comprehensive plan in the mineral sector by mineral employers to implement such the law notably in the construction for processing and refining minerals. Therefore, to ensure the availability of raw materials for domestic processing and refining as well as to prevent the negative impacts of the environment, it is absolutely required to control the mineral export through the construction of domestic mineral processing plants, as conducted by $\mathrm{PT}$. ANTAM and PT. ICA. Both companies have built a processing plant that processes the bauxite ores into chemical grade alumina (Kementerian Energi dan Sumber Daya Mineral, 2012)

Law Number 4 of 2014 and Government Regulation No. 23 of 2010 regarding the compulsion of mining entrepreneurs not to export raw materials but to process its raw materials to be intermediate or finished goods. This will provide a benefit as it can increase the value added to the company, employees, 3rd party (consultants, surveyors and other services), state and regional revenue (royalties, local taxes and corporate income tax), as well as to fulfill the needs of raw materials for domestic industrial supplied that is by imports big Such the fact reduces foreign exchange.

The fact that the existence of processing plant provides a bigger increase of the value 
added encourage the goverment to improve the domestic bauxite processing into smelter grade alumina of chemical grade alumina instead of making such materials as commercial commodities. Technology to process bauxite into alumina is important in Indonesia to get its optimum value added. The fact that the existence of processing plant provides a bigger increase of the value added encourage the goverment to improve the domestic bauxite processing into smelter grade alumina or chemical grade alumina instead of making such materials as commercial commodities. Technology to process bauxite into alumina is important in Indonesia to get its optimum value added.

Kustiari (2011) stated that concerning the procesing the value-added is defined as the difference between the product value with the raw material and other input raw material and other input costs without the cost for the labors, whitout the cost for the labor but not including labor. Margin refers to the difference between the product value and the price of its raw materials. Margin covers used production components such as labor, another input, and fringe benefits processing business. According to Kamisi (2011), the increase of value-added occurs due to the value development from the presence of functional input of treatments and services that cause the increase of the usefulness and commodity value.

In fast growing global trade era along with the increas of community needs the role of processing products produced from one country and is required by another country make such products more effective and provide the important position of the country as teh producer (Kotler and Keller, 2010).

Exporting the raw bauxite make a detrimental to the Republic of Indonesia as the bigges bauxite producer. A big value added from such product is prossessed by the importers after they process the raw materials into the finished goods and sell them to either origin or other countries.

Indonesia will be taken into account as a bauxite producer country after having CGA processing plant owned by PT ICA and SGA owned by PT ANTAM. The existence of both plants helps Indonesia to diminish the loss due to exporting the raw bauxite. In addition, both plants will also meet the alumina need of PT INALUM arount 550,000 tons a year.

In 2015, the mandate of Indonesian mining law was well responded by PT ANTAM by establishing 300.000 metric ton CGA plant at Tayan in colaboration with Showa Denko of China. The plant processes $1,700,000$ tons raw bauxite that was equivalent to 850.000 tons washed bauxite. The first production was conducted in 2015. The CGA plant with the value of the project around US\$450 million will produce the CGA that can be used for fulfilling industrial domestics as a filler in cosmetics industries (nail polisth, lipstick, sublock), a catalyst for alcohol dehydration, a dewatering agent in a gas current in chemical industries, a polisher agent for CD/DVD, a harmless and environmental friendly for spot and pigment remover of cosmetics effect compared to similar materials that use plastic materials. The CGA can also be applied as supporting materials for functional and electronic components such as refractories, abrasives, building materials, IC, LCD screen, ets.

Sugiharto (2008) stated that each entrepreneur commonly will make efforts to make their investments develop properly corresponding with company's goal, namely getting a big profit. To support the CGA plant, it is necessary to analyze the value-added of CGA selling compared to bauxite raw mateial seling. Analysis result shows that the profit of finished goods selling is bigger than that of raw material selling.

Five assumptions were used to analyse the increase of value added namely (Kasmir and Jakfar, 2007):

1. The past costs were not considered as the cost, because the project represented cash flows for the next future.

2. Cash flow in the project based on the profit but the non cash loan as depreciation and amortization will be taken into account.

3. Investments for establishing the plant comes from the owner. As a result thel interest rate must be calculated and paid as it was assumed as loan capital.

4. The tax will be a reduction from the calculation of benefit and is considered as an expense.

5. The interest rate will be calculated and assumed to be a similar level to the interest rate (discount factor). 
Analyzing the increase of value-added in a business project is to determine the investment plant through calculation of the costs and the expected benefits by comparing the expenditures and revenues such as the availability of funds, capital cost the project' ability to repay the funds within a predetermined time and the evaluate whether the project will continually develop and provide benefits (Umar, 2009).

Hartanti (2004) said that such an analysis is an activity to answer the questions from the owners when implementing their investment whether the project provides benefits or not in the future. Muzakir (2007)) stated that the financial analysis is an activity to assess the investment plan investment. Similiar to (Hartanti, 2004), Rajaratnam, Hardjasaputra and Girianna (2006) said that a Financial analysis determines whether a project provides benefits or not if the project is be run.

The increase of value-added evaluation is mainly the effort to evaluate financial feasibility by observing the financial benefits that can be obtained by the investors as well as the economic benefits that can be acquired by the community, region or country (Widianto, 2008). Next stages, according to Subagyo opinion (2008), need analyzing some important things that will make the company gets can compete continuely and gets a decent profit The cecessary analyses include analysis supply and demand, sales, market segmentation, strategy and marketing implementation such financial analysis will provide more optimum results

\section{CONCLUSION AND RECOMMENDATION}

\section{Conclusion}

1. Based on the analysis of the calculation of value added from sales of bauxite ore and chemical grade alumina product, it can be concluded that the company could sell bauxite ore as much as 1.7 million tons (as crude bauxite) or 850,000 tons(as washed bauxite) with the price of US $\$ 19$ per ton.

2. The value-added of the total bauxite ore sales amounted to the US \$8,923,273 and value-added of the sale of chemical grade alumina, into the US $\$ 57,238,237$ (Rp. 754399963 660).
3. The profit from ors selling was the US $\$$ $5,726,449$ while the profit from chemical grade alumina was the US $\$ 22,000,871$.

4. The value-added is 10.49 per ton that comes from the total value-added US $\$$ $8,923,273$ and the sale of 850,000 tons of bauxite ore. While the value-added of US $\$ 190.79$ per ton was derived from the total of value-added of US $\$ 57,238,237$ and the selling of 300.000 ton chemical grade alumina.

5. 2013 is the last year came into effect of bauxite ore export sales. It will create value-added of bauxite ore sales amounted to the US $\$ 419,918,729$ of the total Indonesian production to reach about 40.000.000 tons. From the sale of chemical grade alumina with the same amount of production amounted to $40,000,000$ million tons, it is equivalent to $7,058,823$ chemical grade alumina (1.7 million tons of bauxite equivalent of 300,000 tons of chemical grade alumina), it will create value-added of US $\$$ $1,346,725,941$.

\section{Recommendation}

Based on the analysis, discussion and conclusions, it is recommended:

1. Though PT ICA has a big profit from selling the CGA, it is suggested to make its produkction expenditures efficient. The objective is PT ICA's CGA can compete with the similar product from China.

2. (PT. ICA) shoud intensify its production in terms of gaining bigger income and being a bigger company.

3. Increasing production capacity will affect PT ICA to get a greater value-added and profitable businesses as well as local gross regional domestic product (GRDP).

4. PT. ICA should more concern in recruiting the local employees to improve the local economic growth surrounding mining area.

5. Aroad map of the need and material potency of material availability for downstream industries in Indonesia is required. Such a road map contains not only metal but also industrial minerals to make other companies that are currently still difficult to build a processing plant can emulate the model made by PT ICA.

6. It is required a tight cooperation between the Ministry of Energy and Mineral Resources, the Ministry of Industry and the Ministry of Trade for bridging the 
supply and demand in the upstream and downstream industries.

7. Providing incentive to other mining entrepreneurs that produce final products (smelting) and conduct a research dealing with value added.

8. The government should minimize the hampering factors such as undercapitalized of small-scale mining, limited energy source for establishing smelter plant and restricted infrastructures

\section{ACKNOWLEDGEMENT}

I would like to thank the Head of Mining and Energy Office of the West Kalimantan Province which for his support, the Directors of PT. ANTAM and PT. ICA (Indonesia Chemical Alumina) in Tayan, who provided data and information regarding the bauxite and alumina industries this study Hopefully this study benefits for all those who are interested in Indonesian bauxite and alumina mining industry.

\section{REFERENCES}

Amalia, D., Aziz, M., Saleh, N., Yuhelda, Somantri, S. and Sofyan, Y. (2011) Pembuatan alumina mettalurgical grade dari larutan sodium aluminat melalui proses pemurnian. Bandung.

Aziz, M., Muta'alim, Rochani, S., Pramusanto, Husaini, Ardha, N., Saleh, N., Amalia, D., Wahyudi, A., Iriansyah, R. and Somantri, S. (2007) Pengolahan dan pemanfaatan red mud limbah industri alumina, Tayan. Bandung.

Bank Indonesia (2016) Laporan perekonomian Indonesia dan kurs transaksi valuta asing terhadap rupiah antar bank di pasar domestik.

Dinas Pertambangan Propinsi Kalimantan Barat (2015) Pertambangan mineral dan batubara Propinsi Kalimantan Barat. Pontianak.

Hartanti, T. (2004) Evaluasi kelayakan leasing sepeda motor pada Koperasi Karyawan Maxus. Universitas Gunadarma.

Husaini, Mutaálim, Zulkarnaen, Azhari, Pendi, S., Rustendi, D. and Sugandi, B. (2009) Aplikasi proses upgrading bauksit dan tailing pencucian bauksit Tayan dan Pulau Kijang. Bandung.

Kamisi, L. (2011) "Analisis usaha dan nilai tambah agroindustri," Jurnal Agrikan, 4(2), pp. 82-87.

Kasmir and Jakfar (2007) Studi kelayakan bisnis. Edisi 2. Jakarta: Kencana.

Kementerian Energi dan Sumber Daya Mineral (2012) Kajian kebijakan pengembangan industri mineral sebagai kawasan ekonomi khusus studi kasus Provinsi Kalimantan Barat. Jakarta.

Kotler, P. and Keller, K. L. (2010) Manajemen pemasaran. Jilid 2, E. Jakarta: Erlangga.

Kustiari, R. (2011) "Analisis nilai tambah dan balas jasa faktor produksi pengolahan hasil pertanian," in Seminar Nasional Petanidan Pembangunan Pertanian, pp. 75-85.

Muzakir, F. (2007) Analisis penilaian invesatasi bisnis waralaba ritel swalayan pada CV. Baswara Investama. Universitas Gunadarma.

PT. Aneka Tambang (2015) Laporan tahunan PT. Aneka Tambang. Jakarta.

Pusat Sumber Daya Geologi (2014) Laporan akhir pemutakhiran data dan neraca sumber daya mineral. Bandung.

Rajaratnam, Y., Hardjasaputra, H. and Girianna, M. (2006) "Studi kelayakan ekonomi pengembangan Bandara Udara Internasional Minangkabau (BIM)," Jurnal Teknik Sipil, 3(2), pp. 81-91.

Salavati, M. (2010) "Smelter grade alumina structure and properties and effects on smelter operations," Journal of Molecular Catalysis A: Chemical, 111(6), pp. 164-175.

Slamet (2005) "Nilai tambah dan balas jasa faktor produksi pengolahan hasil-hasil pertanian," Bulletin Penelitian Kementerian Pertanian, 8, pp. 1-8.

Subagyo, A. (2008) Studi kelayakan teori dan aplikasi. Jakarta: PT Elex Media Komputindo.

Sugiharto, T. (2008) "Studi kelayakan finansial pada perusahaan mebel PT. Maju Jaya," Jurnal Ekonomi dan Bisnis, 7(3), pp. 145-153. 
INDONESIAN MINING JOURNAL Vol. 19, No. 3, October $2016: 167$ - 178

Suripto (2011) Manajemen keuangan, strategi penciptaan nilai perusahaan melalui pendekatan economic value added. Yogyakarta: Graha IImu.

Umar, H. (2009) Studi kelayakan bisnis. Edisi 5.

\section{Jakarta: PT Gramedia Pustaka Umum.}

Widianto, M. (2008) Analisis kelayakan investasi untuk pengembangan usaha pada $\mathrm{CV}$. Usaha Hidup Istiqomah. Univesitas Gunadarma. 